\title{
Long Run Effects of Export Instability on Economic Growth of Ethiopia: Cointegration Analysis
}

\author{
Lambamo Arega Gashe \\ Wolaita Sodo University, Ethiopia
}

\begin{abstract}
This study investigated the hypotheses that whether export instability adversely affects the economic growth of Ethiopia in the long run using the data over the period of 1981-2017. For this purpose the paper employed econometric and different statistical techniques to determine export instability index and the long run relationships of cointegrating variables. The Augmented Dickey Fuller (ADF) and Johansen Cointegration tests are also used to test stationarity for all variables and cointegration respectively. The ADF test result revealed that all variables are non-stationary at levels but stationary at their first difference and integrated of order I(1). The Johansen Cointegration test result also suggested that there exists a unique long-run relationship among the variables entered in to the model. The investigation demonstrated that export instability has deleterious effect on economic growth. The study also found that export, human capital and consumption have significantly positive effects on economic growth. However, Gross capital formation has reflected puzzling effect on economic growth. This result may be due to the fact that export instability is causing the whole macroeconomic instability. The policy implication is that the government has to follow an export oriented measures whereby such fluctuations can be smoothed out, like diversification of export portfolio, if the country is to secure rapid and sustained economic growth in the long run.
\end{abstract}

Keywords: Export instability, Economic Growth, Cointegration, Investment

DOI: $10.7176 / \mathrm{JESD} / 10-9-06$

Publication date:May $31^{\text {st }} 2019$

\section{INTRODUCTION}

Ethiopia's economy, like many other developing countries, is mainly characterized by a large saving-investment gap, government budget deficit and current account imbalance. Besides smallness of export volume, unstable export earnings may be considered as a gap generating factor in the economy. The detrimental effects of export instability may be transmitted to the economic growth through saving and investments by widening the gap and raising budget deficits. Unpredictable fluctuation in export proceeds will cause fluctuation in earning of export product producing firms. On the other hand revenue of the government from export in the form of taxes may be disturbed (Chaudhary and Qaisrani, 2002). This calls the government to raise funds from borrowing to finance the budget deficit; hence both investment and economic growth may be significantly affected.

In the last five decades Ethiopian economy experienced continuously increasing resource gaps. The savingsinvestment gap on average was 1.79 percent of GDP during the Imperial period (1960/61-1973/74) which also increased to 6.18 percent of the GDP during the Dergue period (1974/75-1990/91) then jumped to 13.8 percent of the GDP in the EPRDF (1991/92- 2014/15). Similarly trade related gap, hence inadequate availability of foreign exchange reserve inherently practiced, it has been widening from 1.79 percent of GDP on average during 1960/611974 to 5.28 percent of GDP during dergue and then rose to 14.04 percent of GDP in the EPRDF (1991/922014/15) (Lambamo, 2017). Hence, dependence on foreign trade earnings and capital inflows has become an important means to sustain and enhance the economic growth which is deteriorating by the scarcity of domestic resources (Lambamo, 2017).

In international trade, least developed countries including Ethiopia are mainly characterized by exporting unprocessed agricultural primary products. Besides this, the export of the goods is also geographically concentrated into few destination countries of the world which is the major cause for instability in the export earnings (Abebe, 1991). Such high concentration in few commodities and few destinations could result in instability of export earnings, which in turn will affect capital formation and growth. Developing countries should avoid heavy dependence on limited products since it diminishes the state's potential to partially offset fluctuations in some export sectors in which stability prevails (Love 1986). The prices of these primary products are low and more volatile in international markets (Rashid et. al., 2012). With this economic structure, export sector of least developed countries has been influenced by low volume of export products, low degree of diversification of exports, inelastic and unstable demand and supply of their exports (Savvides, 1984).

Ethiopia's export sector which is highly dominated by few agricultural products are highly vulnerable to change in price in international market due to internal, external and natural shocks. This instability in export proceeds may cause fluctuations in foreign exchange reserves which in turn constrains import requirements of essentials investment capital goods. Such instability has been a bottleneck for the economic growth of the country by constraining input and production planning. 
With this scenario, it is argued that the economic growth of developing countries has been worsening by the detrimental effects of export instability which resulting fluctuations of export proceed. The aim of this paper is to examine the argument that whether the economic growth of Ethiopia is adversely affected with unstable export proceeds and to determine the relationship between economic growth and export earnings. Concerning this issue, different empirical investigations were conducted by different scholars in developing countries within the neoclassical production function in studying the relationship between exports and economic growth in which output level is a function of different factors inputs such as labor, capital and exports. However, some scholars have come with the conclusion that there is no statistically significant evidence that indicating export instability is adversely affecting economic growth and some concluded that volatility of export proceeds have dampened economic growth of these developing countries. In this article, we study export instability and economic growth with different methodological approach within the framework of cointegration analysis. The estimation is preceded by extensive stationarity tests so that we avoid estimating spurious regressions.

\section{Objectives of the study}

This study is designed to empirically investigate the following issues. And a result of the study is expected to throw light for policy-makers in making decisions or policy interventions regarding export sector.

i. To examine long run effect of export earnings instability on the economic growth of Ethiopia

ii. To forward policy suggestions.

\section{REVIEW OF RELATED EMPIRICAL LITERATURE}

In this section, previously conducted studies are reviewed; and these studies found three possible results. Some studies have found a positive relationship between export instability and economic growth; some other studies found negative relationship while some other studies suggested no relationship between export instability and economic growth.

Sinha (1999) examined the relationship between export instability, investment and economic growth in nine Asian countries using time-series econometric techniques. The analysis revealed variety of results between export instability and economic growth for these countries. The study found a negative relationship between export instability and economic growth for Japan, Malaysia, Philippines and Sri Lanka and established a positive relationship for South Korea, Myanmar, Pakistan and Thailand. In the case of India, the results were mixed, as an identification problem arose due to two cointegrating vectors. It is not generally sufficient just to determine the number of cointegrating relations among the included variables. The final aim should be an empirical model of the long-run and short-run structure in order to gain a better understanding of how the economy works.

Chaudhary and Qaisrani (2002) analysed the effects of export instability on domestic savings, investment and,hence, overall economic growth of Pakstan using OLS estimation technique. Their empirical findings revealed that export instability does not affect economic growth and investment in Pakistan. The study found that excessive reserves of foreign exchange enhance capital formation and have positive impact on increasing output. The instability in exports also does not seem to affect imports of capital goods and domestic investment. Krishan et. al., (2008) investigated the relationship between economic growth, export growth, export instability and gross fixed capital formation in India during the period 1971- 2005. They employed Johansen co-integration analysis and a vector error-correction model to investigate the relationship among the variables. They found unidirectional causal relation running from real exports to real GDP. From the error correction model they concluded that an increase in export instability has a negative effect on economic growth in the short-run and supports the contention that export instability induces short-run macroeconomic instability while in the long-run it contributed positive effect.

Farhat et al., (2012) analysed the hypothesis that export instability affects the economic growth for all selected SAARC region countries (Pakistan, India, Sri-Lanka and Nepal) by the framework of neoclassical aggregate production function including export and export instability as the additional variables. They concluded that export instability has affected economic growth four countries and the effect is more series for Sri Lanka economy. They also found statistically significant and positive effect of exports and investment on economic growth for all countries while export explained negative effect on its economic growth of Nepal.

\section{III.Data source and Empirical models}

\subsection{Data Source and variable description}

Annual time series data were used from 1981 to 2017. The data were taken from National Bank of Ethiopia (NBE), Ministry of Finance and Economic Development (MOFED), World development indicator (WDI) and International Financial Statistics (IFS) and ILO. The following variables are used in the study: LNRGDP (log of real GDP), LNEXPO (log of exports of goods and services), LNHC (log of Human capital), LNGCF (log of gross capital formation - a measure of investment), LNCNS (log of consumption - sum of public and private final consumption) and EINS (export instability). Except export instability, all variables are in log form, the first 
differences give us the growth rates of these variables.

\section{Measure of Export Instability Index}

Export instability is universally defined as an unpredictable deviation over an observed time series with respect to its trend. It is expected to show unpredictable fluctuation in pattern, it may grow positively, negatively or stay constant following some pattern which is commonly called the 'trend'. Therefore, in order to work on a de-trended data basis much effort has applied to specify the trend function employed to estimate the residual variability in export earnings. This is because many literatures were argued that the estimation results of export instability and economic growth is highly sensitive to different trend functions. Therefore, the functional form used to eliminate the trend is realized directly from the actual performance of each time series data and the trend factor has been determined by using OLS estimation method. A log-linear trend function is used in this paper, since, the t-test, Ftest and DW-test are statistically significant and the trend function having the highest $\bar{R}^{2}$ it best fits criteria.

$$
\log E X P=\alpha+\beta t+\varepsilon_{t}
$$

Export instability index have been measured by different methods such as coefficient of variation, moving average method, absolute difference between actual export earnings and the trend values of export earnings etc.

Cuddy-Della Valle (1978) evaluated Export earnings instability index as: $I_{x}=C V \sqrt{1-\bar{R}^{2}}$, where $\mathrm{CV}$ is the coefficient of variation of the time series of the export earnings and $\bar{R}^{2}$ is the adjusted coefficient of determination of the trend function that best fits the actual export proceeds. Based on Cuddy-Della Valle (1978) proposition this study employed the following procedure to measure the export instability index as follows:

$$
E I N S=\left(\frac{\sqrt{\frac{(\log E X P O-\log \overline{E X P O})^{2}}{T}}}{\overline{l o g E X P O}} * 100\right)\left(\sqrt{1-\bar{R}^{2}}\right),
$$

Where EINS is export instability, $\bar{R}^{2}$ is the adjusted coefficient of determination of the trend function, $\log E X P O$ is $\log$ of export, $\mathrm{T}$ is the time period.

\section{EMPIRICAL MODEL SPECIFICATION}

In this article the generalized Johansen framework of cointegration tests and vector error correction model is employed. The general form of the vector error correction model (VECM) is given by:

$\Delta \boldsymbol{H}_{t}=\alpha\left(\boldsymbol{\beta}^{\prime} \boldsymbol{z}_{t-1}\right)+\sum_{i=1}^{k-1} \Gamma_{i} \Delta \boldsymbol{H}_{t-i}+\delta D_{t}+\xi_{t}$

where $\boldsymbol{H}_{\mathrm{t}}$ is a vector of endogenous variables described as LNRGDP, LNGCF,LNCNS, LNHC, LNEXPO and EINS. $i$ denotes the selected lag length; $\alpha$ and $\beta$ are coefficient matrices, $\beta^{\prime} z_{t}$ defines the stationary long-run cointegrating relations and $\alpha$ denotes the adjustment coefficients to the equilibrium error (Juselius, 2005). Hence, taking into account of using shift dummy, our statistical analysis and results become appropriate because it is used as a control for the shocks of policy shift on the variables; and it is designed to take value 1 after 1991 and zero otherwise. And $\xi_{\mathrm{t}}$ is a vector of unobservable error terms, that are assumed, $\xi_{\mathrm{t}} \sim \operatorname{iidN}(0, \Omega), \Delta$ is the difference operator,

\section{Stationarity/Unit root test of the variables}

Most of the time series datas are characterized by stochastic trends hence testing for the existence of unit roots(non stationarity of data) is important. Because regressing with the presence of unit root will result in spurious results hence, ones the problem is detected, we can avoid such problem by defferencing. In this regard, Dickey and Fuller developed a test to assess the existence of unit root known as Augumented Dickey-Fuller test. This test estimates the following equations:

$$
\begin{aligned}
& \Delta z \mathrm{t}=\beta_{0}+\theta z_{\mathrm{t}-1}+\sum_{\mathrm{i}=1}^{m} \delta i \quad \Delta z_{t-i}+\varepsilon_{\mathrm{t}} \quad \ldots \ldots \ldots \ldots \ldots \text { intercept only } \\
& \Delta z \mathrm{t}=\beta_{0}+\beta_{1} \mathrm{t}+\theta z_{\mathrm{t}-1}+\sum_{\mathrm{i}=1}^{m} \delta i \quad \Delta z_{t-i}+\varepsilon_{\mathrm{t}} \ldots \ldots \ldots \ldots \ldots \text { with trend and intercept } \\
& \Delta z \mathrm{t}=\theta z_{\mathrm{t}-1}+\sum_{\mathrm{i}=1}^{m} \delta i \quad \Delta z_{t-i}+\varepsilon_{\mathrm{t}} \ldots \ldots \ldots \ldots \ldots \ldots \ldots \ldots \text {. } \ldots \ldots \ldots \ldots \text {. }
\end{aligned}
$$

The null hypothesis of the existence of a unit root is $H 0: \theta=0$. If the null hypothesis is rejected, the variable is stationary. For the estimated parametres of lagged variable in the equation, we accept the null hypothesis if the calculated test statistic in absolute value is less than the critical value.

Table 1. Stationarty test of variables at level.

\begin{tabular}{|c|c|c|c|c|c|c|c|}
\hline \multicolumn{2}{|c|}{ Variables } & $\ln R G D P$ & $\ln G C F$ & $\ln L F P R$ & $\ln C O N S U M$ & $\ln E X P$ & EINS \\
\hline \multicolumn{2}{|c|}{ Test statistic } & $\mathbf{- 0 . 0 7 0}$ & $\mathbf{- 1 . 7 1 3}$ & $\mathbf{- 1 . 8 8 8}$ & $\mathbf{0 . 3 8 8}$ & $\mathbf{- 2 . 3 7 5}$ & $\mathbf{- 2 . 6 2 8}$ \\
\hline \multirow{2}{*}{$\begin{array}{c}\text { Critical } \\
\text { value }\end{array}$} & $1 \%$ & -4.297 & -4.297 & -3.689 & -4.297 & -4.297 & -4.297 \\
\cline { 2 - 8 } & $5 \%$ & -3.564 & -3.564 & -2.975 & -3.564 & -3.564 & -3.564 \\
\cline { 2 - 8 } & $10 \%$ & -3.218 & -3.218 & -2.619 & -3.218 & -3.218 & -3.218 \\
\hline \multicolumn{2}{|c|}{ Order } & $\mathrm{I}(1)$ & $\mathrm{I}(1)$ & $\mathrm{I}(1)$ & $\mathrm{I}(1)$ & $\mathrm{I}(1)$ & $\mathrm{I}(1)$ \\
\hline
\end{tabular}


The regresion out put for the unit root test by using Augmented Dickey Fuller(ADF)test indicate that the hypothesis of variables are not stationary is accepted at $1 \%, 5 \%$ and $10 \%$. Therefore, the variables are not stationary at level.

Table 2. Stationarity test of variables at first Difference

\begin{tabular}{|c|c|c|c|c|c|c|c|}
\hline \multicolumn{2}{|c|}{ Variables } & $\triangle \ln R G D P$ & $\triangle \ln G C F$ & $\triangle \ln L F P R$ & $\triangle \ln C O N S U M$ & $\triangle \ln E X P$ & $\Delta E I N S$ \\
\hline \multicolumn{2}{|c|}{ Test statistic } & -3.281 & -7.525 & -4.056 & -6.416 & -7.743 & -6.943 \\
\hline \multirow{3}{*}{$\begin{array}{c}\text { Critical } \\
\text { value }\end{array}$} & $1 \%$ & -2.453 & -4.306 & -2.453 & -4.306 & -4.306 & -4.306 \\
\hline & $5 \%$ & -1.696 & -3.568 & -1.696 & -3.568 & -3.568 & -3.568 \\
\hline & $10 \%$ & -1.309 & -3.221 & -1.309 & -3.221 & -3.221 & -3.221 \\
\hline \multicolumn{2}{|c|}{ Order } & $\mathrm{I}(0)$ & $\mathrm{I}(0)$ & $\mathrm{I}(0)$ & $\mathrm{I}(0)$ & $\mathrm{I}(0)$ & $\mathrm{I}(0)$ \\
\hline
\end{tabular}

The ADF test result indicates that all variables at the first difference are significant at $1 \%, 5 \%$ and $10 \%$. This result indicates that all the variables are nonstationary in their levels but stationary in their first differences. Thus, we can perform the cointegration tests and employ VECM.

\section{Lag length selection (determination)}

Once all the above factors that influence the analysis, statistical inference and economic interpretation are included in the model, lag length determination test will be valide and hence under this condition the correct length will be determined (Juselius, 2005). The followings are different types of tests to determine significant lag length of the model.

$$
\begin{array}{lc}
\mathrm{AIC}=\ln |\Omega|+\left(\mathrm{p}^{2} \mathrm{k}\right) \frac{2}{T} & \text { where, }|\Omega| \text { is the determinant of residual covariance matrix, } \\
\mathrm{SBIC}=\ln |\Omega|+\left(\mathrm{p}^{2} \mathrm{k}\right) \frac{\ln T}{T} & \mathrm{~T} \text { is significant observations, } \mathrm{p} \text { is number of variable, } \\
\mathrm{HQIC}=\ln |\Omega|+\left(\mathrm{p}^{2} \mathrm{k}\right) \frac{2 \ln \ln T}{T} & \mathrm{k} \text { is number of lags }
\end{array}
$$

All of these information criterias are based on the maximal value of the LL function with an additional penalizing factor related to the number of estimated parametres. Hence, the choice of the significant lag(k) determined based on the obtained smallest value of information criteria.

Table:4.3. Lag length determination test result

\begin{tabular}{|c|rllccccc|}
\hline lag & LL & LR & df & p & FPE & AIC & HQIC & SBIC \\
\hline 0 & 15.7213 & & & & $2.2 e-08$ & -.607581 & -.516484 & -.332755 \\
1 & 161.562 & 291.68 & 36 & 0.000 & $2.4 e-11^{*}$ & -7.47262 & $-6.83494^{*}$ & $-5.54884^{*}$ \\
2 & 199.56 & 75.997 & 36 & 0.000 & $2.7 e-11$ & -7.59753 & -6.41327 & -4.0248 \\
3 & 246.35 & $93.578 *$ & 36 & 0.000 & $3.0 e-11$ & $-8.27186 *$ & -6.54102 & -3.05017 \\
\hline
\end{tabular}

Finally, a maximum lag is determined based on the information criteria i.e Schawartz Bayesian information criterion (SBIC), Hannan Quin Information Criterion (HQIC) and FPE indicates a significant lag length of one while Likelihood Ratio(LR) and Akakie Information Criterion (AIC) indicates a lag length of three. The correct lag is determined based on majoriy of information criteria accordingly the lag length of one is appropriate.

Determination of cointegration rank: Johanson test for cointegration rank

The existence of Cointegration among the variables in the system implies a linear combinations of the variables of the vector process that are integrated of lower order than the process itself. The linear combinations $\boldsymbol{\beta}^{\prime} \boldsymbol{z}_{\mathrm{t}}$ become stationary even the variables are non-stationary and hence, move together in the long run. Then the variables have long run relationship or cointegrated from I(1), having reduced order than the series. In such cointegrated relations, $\boldsymbol{\alpha} \boldsymbol{\beta}^{\prime} z_{t}$ can often be interpreted as long-run economic steady-state relations (Juselius 2005).

The table below, trace test indicates that there is one cointegrating relation among the variables. 
Table 4.5: Johansen tests fort Cointegration rank

\begin{tabular}{|ccccccc|}
\hline $\begin{array}{c}\text { maximum } \\
\text { rank }\end{array}$ & parms & LL & eigenvalue & $\begin{array}{c}\text { trace } \\
\text { statistic }\end{array}$ & 5\% critical \\
value & 1\% critical \\
0 & 0 & 266.27657 & & 122.4017 & 82.49 & $\begin{array}{c}\text { value } \\
1\end{array}$ \\
11 & 298.59324 & 0.85058 & $57.7684 * 1 \star 5$ & 59.46 & 66.52 \\
2 & 20 & 311.17541 & 0.52295 & 32.6041 & 39.89 & 45.58 \\
3 & 27 & 318.77451 & 0.36046 & 17.4059 & 24.31 & 29.75 \\
4 & 32 & 324.56325 & 0.28860 & 5.8284 & 12.53 & 16.31 \\
5 & 35 & 326.7203 & 0.11917 & 1.5143 & 3.84 & 6.51 \\
6 & 36 & 327.47744 & 0.04356 & & & \\
\hline
\end{tabular}

\section{IV.RESULT AND DISCUSSIONS \\ 4.1 LONG RUN RESULTS}

The matrix of normalization and restriction imposed cointegrating relations and the matrix of adjustiment coefficients are presented in table 4.1 below. A variable in adjustiment coefficient matrix is said to be adjusting to the equilibrium when it has significant t-ratio and have opposite sign to the corresponding cointegrating relation coefficients, when this is the case the cointegration relation is equilibrium correcting in the equation $\Delta \boldsymbol{H}$.

The equilibrium correction relation explores how the process is pulled towards equilibrium position(steady state) with the force of adjustiment coefficients which activates immidiately when the process is above or below equilibrium position $\left(\boldsymbol{\beta}^{\prime} \boldsymbol{z}_{t}-\boldsymbol{\beta}_{\boldsymbol{0}} \neq \boldsymbol{0}\right)$ due to internal and external shocks. When this condition happens the adjustiment coefficients may force the process back towards the equilibrium position with the velocity of adjustiment depending on the length of adjustiment coefficient and size of equilibrium error. The cointegrating relation equation describes a system at rest(steady state) or stationary when there is "no economic adjustiment forces(incentive) to change the system to a new position'(Jusilius, 2005). These error correction term or cointegrating relations represent stationary linear combination of the cointegrated variables. When the adjustiment coefficient(let say $\boldsymbol{\alpha}_{i j}$ ) and the equilibrium relation coefficient(let say $\boldsymbol{\beta}_{i j}$ ) are of the same sign, the cointegration relation is overshooting rather than adjusting in equation $\Delta \boldsymbol{H}_{\mathrm{t}}$.

This finding suggests that there is one cointegrating (long-run equilibrium) relationship among the variables, and any departure from this equilibrium relationship may be due to temporary disequlibrating forces. The cointegrating relation normalized on $L N R G D P$ is reported in Table 4.1. The normalized equations are obtained by dividing each cointegrating vector by the negative of the estimated log real GDP coefficient. The estimated parameters of this normalized cointegrating equation on the right hand side are long-run equilibrium estimates. The results suggest that export proceeds have highly statistically significant positive effect on economic growth supporting export led growth hypothesis. The estimated coefficient export suggests that a $1 \%$ increase in export would cause a $1.463 \%$ increase in growth. Surprisingly, the result also suggests that final consumption have statistically significant positive association with economic growth. This finding shows that final consumption expenditure turns to be productive and accelerates economic activities in Ethiopia. This finding supported the Keynesian consumption theory, that consumption is an exogenous factor and a policy instrument for increasing economic growth. The estimated coefficient suggests that a $1 \%$ increase in consumption would lead to about $1.193 \%$ rise in economic growth.

The result also suggested that human capital has strong positive association with economic growth; its coefficient suggesting highly elastic. The estimated long run coefficient of export instability its sign is reversed during normalization, which is negative and statistically significant, suggesting export instability is detrimental to economic growth of Ethiopia. This instability leads to the whole economic instability because it would automatically be transmitted to the rest of the economy (Lim, 1976). Hence, the estimate suggests that increase in export instability has a negative effect on the economic growth in the long-run and support the argument that export instability induces long run macroeconomic instability

Surprisingly, the analysis result indicated inverse relationship between gross capital formation and economic growth. This result supports the argument that instability in export proceeds affects the whole economy through a transmission channels affecting saving and investments. This result may be due to the fact that export instability is causing the country to import lower capital investment machineries and goods, which is lowering economic growth through lowering investment. This finding also supports the Lim (1976) basic hypothesis that instability in export earnings reduces the level of investment because of the business miscalculations and speculations it encourages and the inflations it generates. The disturbance of economy (investment) due to export instability transmitted through discontinuous flow of the imports of intermediate and capital goods.

To assist the interpretation, when we see table 4.7 the adjustment coefficients of LNRGDP, LNHC and EINS to the equilibrium were statistically significant at $90 \%, 95 \%$ and $95 \%$ respectively. To correct to the equilibrium 
error the coefficients should have opposite sign to the long run coefficients. The statistical significance of the error correction or adjustment term in the LNGDP equation suggests that LNRGDP adjusts to correct long run disequilibria in exports, consumption, human capital, export and investment. The statistical significance and reverse sign to the corresponding long run coefficient of the error correction or adjustment term in the EINS equation suggests that EINS adjusts to correct long run disequilibria in growth, exports, consumption, human capital and investment. The statistical significance and reverse sign to the corresponding long run coefficient of the adjustment term in the DLNHC equation suggests that $\mathrm{HC}$ adjusts to correct long run disequilibria in growth, exports, consumption, export instability and investment. This implies that the error correcting mechanism will in the long run bring back a series to its long run equilibrium after a shock has happened.

Table 4.6: Cointegrating relation (Long run result)

\begin{tabular}{l|clcccc}
\hline Beta & Coef. & Std. Err. & $\mathbf{z}$ & $\mathbf{p}>|\mathbf{z}|$ & {$[\mathbf{9 5 \%}$} & Conf. Interval] \\
\hline LNRGDP & 1 & & & & & \\
LNEXPO & -1.463138 & .3061629 & -4.78 & 0.000 & -2.063206 & -.8630695 \\
LNCNS & -1.192892 & .5271969 & -2.26 & 0.024 & -2.226178 & -.1596045 \\
LNHC & -28.98627 & 3.683218 & -7.87 & 0.000 & -36.20524 & -21.76729 \\
EINS & 19.01509 & 3.505757 & 5.42 & 0.000 & 12.14394 & 25.88625 \\
LNGCF & 2.285033 & .5184004 & 4.41 & 0.000 & 1.268986 & 3.301079 \\
$\quad$ C & 64.47259 & & & & & \\
\hline
\end{tabular}

Table 4.7: Adjustment parameters

\begin{tabular}{l|clcccc}
\hline Alpha & Coef. & Std. Err. & $\mathbf{z}$ & $\mathbf{p}>|\mathbf{z}|$ & \multicolumn{2}{c}{ [95\% Conf. Interval] } \\
\hline DLNRGDP & .039926 & .021396 & 1.87 & 0.062 & -.002009 & .0818621 \\
DLNEXPO & .0264192 & .0963474 & 0.27 & 0.784 & -.1624183 & .2152567 \\
DLNCNS & -.0409433 & .0494603 & -.83 & 0.408 & -.1378837 & .055997 \\
DLNHC & .0174843 & .00525 & 3.33 & 0.001 & .0071945 & .0277741 \\
DEINS & -.015213 & .0062364 & -2.44 & 0.015 & -.0274361 & -.00299 \\
DLNGCF & -.0477389 & .100994 & -0.47 & 0.636 & -.2456834 & .1502056 \\
\hline
\end{tabular}

\subsubsection{Post Estimation tests}

4.1.2 Misspecification tests:

\subsubsection{Residual Autocorrelation test}

The test of residual autocorrelation deviates from the assumption of uncorrelated residuals and it is important test in the CVAR model, because the test procedures of $x^{2}$ and F-test are based on the uncorrelated residuals. If the model fail to pass the test, all $x^{2}$ and $\mathrm{F}$ tests derived for the VECM model will be distorted and the estimates are inconsistent. The Lagrange Multiplier (LM) test is used to test residual autocorrelation of $\mathrm{h}^{\text {th }}$ order correlation in this paper. The test is distributed as $x^{2}$ with $\mathrm{p}^{2}$ degrees of freedom wih the null hypothesis: H0: no serial correlation at lag order $\mathrm{h}$. If $\mathrm{H}_{0}$ is rejected for the choosen lag order, there is evidence of left-over autocorrelation in the model. However,our test accepted the null hypothesis of no left autocorrelation at lag order h. Hence, the results (reported below) do not suggest any significant left-over autocorrelation for the given lag order 1 to 3 . Hence, the model is correctly specified and the results are consistent and apropriate, so we can accept the results obtained without doubt.

Lagrange-multiplier test

\begin{tabular}{|c|rcc|}
\hline Iag & chi2 & df & Prob $>$ chi2 \\
\hline 1 & 41.3617 & 36 & 0.24802 \\
2 & 33.3646 & 36 & 0.59458 \\
3 & 46.1691 & 36 & 0.11937 \\
\hline
\end{tabular}

HO: no autocorrelation at lag order

\section{Hetroskedasticity test of residuals}

The test for residual heteroscedasticity (either residuals have constant variance or not) is the $\mathrm{p}^{\text {th }}$ order $\mathrm{ARCH}$ (Autoregressive Conditional Heteroscedasticity) test is used in this thesis which described and used in (Juselius, 2005, Martins, 2010). The test is approximately distributed as chi square $\left(\boldsymbol{x}^{2}\right)$ with p degrees of freedom and the Null hypothesis (H0) of LM test for ARCH assumes no ARCH effect i.e. homoscedastic error terms. Table 4.14 below shows that the null of no ARCH effects at univariate level, as the null of homoscedastic errors or no 
heteroscedasticity can never be rejected.

Table 4.10. Residual heteroscedasticity test result.

\begin{tabular}{c|ccc} 
LM test for autoregressive conditional heteroskedasticity & (ARCH) \\
\hline $\operatorname{lags}(p)$ & chi2 & df & Prob > chi2 \\
\hline 1 & 0.127 & 1 & 0.7220 \\
2 & 0.495 & 2 & 0.7807 \\
3 & 0.394 & 3 & 0.9414 \\
\hline
\end{tabular}

$$
\text { HO: no ARCH effects VS. H1: } \operatorname{ARCH}(p) \text { disturbance }
$$

\section{Stability test of the model}

As reported in fig. 4.1The stability nature of the model can be determined based on eigenvalue roots and modulus of the system obtained. A real root $\left|\boldsymbol{\rho}_{j}\right|$ generates exponentially declining behavior while a complex pair of stable roots $\boldsymbol{\rho j}=\boldsymbol{\rho}_{\text {real }} \pm \boldsymbol{i} \boldsymbol{\rho}_{\text {complex }}$ generate exponentially declining cyclical behavior. The real roots that lie on the unit circle $(\rho=1)$, indicates non-stationarity of variables, i.e. a stochastic trend in $\boldsymbol{H}_{\boldsymbol{t}}$. The values of the eigenvalue in real root $\left|\rho_{\mathrm{j}}\right|<1$, and a complex pair of roots $|\boldsymbol{\rho} \boldsymbol{j}|=\left|\boldsymbol{\rho}_{\text {real }} \pm \boldsymbol{i} \boldsymbol{\rho}_{\text {complex }}\right|$ has fallen inside the unit circle, which indicates the generation of declining cyclical behavior. This also agrees with the stability of the system, albeit with different dynamics (Juselius, 2005 and Martins, 2010). If the model is wrongly specified and not stable and cointegrating vectors are non stationary, at least one of the Eigen value root will be indicated outside of the unit circle $\left|\rho_{\mathrm{j}}\right|>1$ indicating exploitive process. But in our model all the Eigen value roots are included with in the unit circle; two unit roots(p-r) and three stationary cointegrating relations $(r=3)$, hence the model stability is accepted successfully. Fig. 4.1: Stability test of the model.

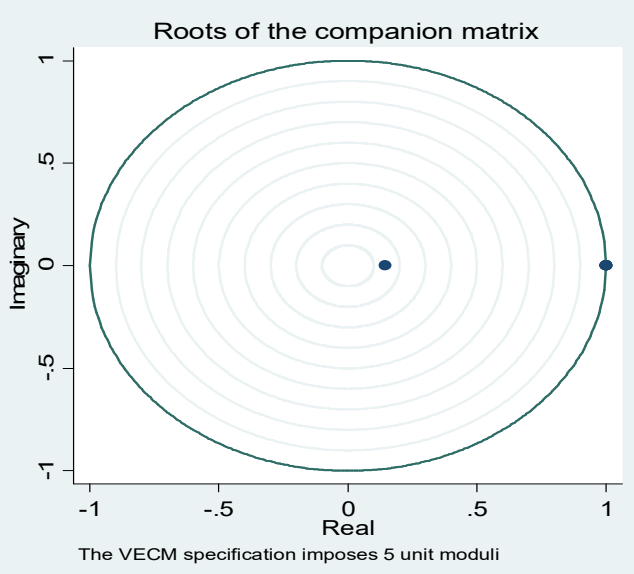

\section{CONCLUSIONS AND POLICY RECOMMENDATIONS}

The hypothesis that export instability affects the economic growth is analyzed in this study for the Etiopian economy by using Cointegration analysis for the period of 1981-2017. To check the stationarity of all variables Augmented Ducky Fuller (ADF) test was used and the test shows all variables are integrated of same order, I(1) at their levels and stationary, $\mathrm{I}(0)$ at first difference and Johansen cointegration technique is used to check long run relationship between economic variables. The empirical results of this study revealed that export instability has negative and significant effects on economic growth of Ethiopia. The result also indicated positive and strong long run relationship between export and economic growth hence provides empirical support that international trade (export) is an important factor for the economic growth of Ethiopia in the long run.

The result of this study leads to some policy implications which can be helpful to reduce the negative effects of export instability on income development and to sustain rapid growth of the economy in the country.

- The government has to follow a policy whereby export fluctuations can be smoothed out.

- The government has to promote and diversify export portfolio horizontally and reduce the geographical concentration from the export sector.

- The government has to set and follow strong evaluation and quality controlling mechanisms the products to be competent in international market.

- Since Ethiopia is mostly an agricultural country, the government should increase the rate of growth of agricultural exports by increasing the export volume, the product's standard, kinds of agricultural product exported, expand the market for agricultural product wider than at the present, and support more of the 
market research.

\section{REFERENCE}

Abebe T. (1991), "Commodity Concentration and Export Earnings Instability: Evidence from African Countries," Center for Economic Research on Africa, Montclair State University. Bulletin of Economics and Statistics, 40, 1, pp. 79-84.

Cuddy J. and Della Valle P.A., (1978), Measuring the Instability of Time Series Data, Oxford

Farhat Rashid, Sami Ullah and Bedi-uz-Zaman(2012). Effects of Exports Instability on Economic Growth in SAARC Region Countries.

Juselius, K., (2005). The Cointegrated VAR model. Methodology and Applications. AdvancedText in Econometrics.

Lambamo Arega (2017). Fiscal Effects of Foreign Aid Flows in Ethiopia:Evidence from Econometric Analysis. International Journal of African and Asian Studies, ISSN 2409-6938. An International Peer-reviewed Journal Vol.30, 2017.

Lim, D . (1976). Export Instability and Economic Growth: A Return to Fundamentals. Oxford Bulletin of Economics and Statistics, 38 (4), 311-322.

Love, J. (1986), "Commodity concentration and export earnings instability: A shift from cross section to time series analysis", Journal of Development Economics (24)2: 239-248.

M. A. Chaudhary and A. A. Qaisrani (2002), Trade Instability, Investment And .Economic Growth In Pakistan. Pakistan Economic and Social Review Volume XL, No. 1 (Summer 2002), pp. 57-73.

Martins, P. M. G., (2010). Fiscal Dynamics in Ethiopia: The Cointegrated VAR Model with Quarterly Data. Economics Departments Working Paper Series 2009-10, University of Sussex.

Savvides, A. (1984). Export Instability and Economic Growth: Some New Evidence. Economic Development and Cultural Change 32(3), 607-614.

Sinha, D. (1999), "Export Instability, Investment and Economic Growth in Asian Countries: A Time Series Analysis", Discussion Paper No. 799, 1999, Economic Growth Center, Yale University. 